\title{
ОСОБЛИВОСТІ ОРГАНІЗАЦІї ВНУТРІШНЬОЇ ТОРГІВЛІ В СРСР У КІНЦІ 1920-Х - ПЕРШІЙ ПОЛОВИНІ 1930-Х РР.
}

\begin{abstract}
Анотація: У статті досліджуються особливості організації радянської внутрішньої торгівлі в умовах централізованого господарювання та пошуку фінансових ресурсів для реалізації програми індустріалізації країни. З'ясовано, що радянська система організації та управління торгівлею еволюціонувала від повного заперечення торгівлі як виду діяльності, до їі перетворення у важливий чинник радянської соціально-економічної моделі. Розвиток радянської торгівлі здійснювався у складних умовах тотального дефіциту, що обумовлювало певний час ї співіснування із системою спецрозподільників. Надійним джерелом поповнення золотовалютних резервів стала торгзінівська торгівля.
\end{abstract}

Ключові слова: СРСР, УСРР, радянська торгівля, державне регулювання, індустріалізація, валюта, торгзін

Державне регулювання торгівлі було і залишається одним із важливих чинників її участі в економічному житті країни. Періоди соціально-економічних і політичних трансформацій тільки посилюють цей процес. Кінець 1920-х - перша половина 1930-х рр. в СРСР став періодом нестабільності, породженим модернізаційними експериментами. Саме тоді розпочала своє формування державна модель радянської торгівлі. Для правильного розуміння теперішнього складного, в економічному плані, часу, вивчення цього періоду української історії представляє для сучасних дослідників особливий інтерес.

Досвід організації радянської торгівлі означеного періоду в умовах централізованого господарювання з його специфічними особливостями актуальний ще й тому, що може стати прикладом радикальних реформ у сфері товарного розподілу, виявити характер взаємодії з приватним сектором економіки та розкриває специфіку функціонування командно-адміністративної системи, яка на певному етапі забезпечувала доступність цін та якість товарів на внутрішньому ринку.

Автор даної статті має на меті проаналізувати особливості організації радянської внутрішньої торгівлі періоду форсованої індустріалізації та методи отримання додаткового фінансування для її потреб.

В історіографії окресленої наукової проблеми вкрай мало окремих, самостійних досліджень, які були б присвячені історії формування та розвитку внутрішньої торгівлі СРСР означеного періоду, з'ясуванню її місця та ролі в економіці країни. Цей період особливий в історії XX ст. Він характеризується неоднозначністю і серед наукового това-

\footnotetext{
* Кузнець Тетяна Володимирівна - доктор історичних наук, професор, завідувач кафедри історії України Уманського державного педагогічного університету імені Павла Тичини; ORCID: https://orcid.org/0000-0002-9282-110X; e-mail: tetiana.kuznets@gmail.com
} 
риства часто викликає діаметрально протилежні оцінки ${ }^{1} .3$ наявних досліджень сучасних істориків маємо праці², де автори вважають, що у 1930-х рр. в умовах мобілізаційнорозподільчої економіки, яка штучно підтримувала низький матеріальний рівень суспільства, основним мотивом економічної поведінки ставав пошук допуску до дефіцитних ресурсів. Сталінський режим, на їх думку, штучно створював видимість соціальної гармонії. 3 одного боку - запроваджував карткову систему, спецмагазини, товарний розподіл, з іншого - проводив боротьбу зі спекуляцією, створював дефіцит і черги.

Радянська система організації та управління торгівлею еволюціонувала від повного заперечення торгівлі як виду діяльності, що, на думку більшовиків, не міг бути властивим новому суспільству, до перетворення iï у важливий чинник радянської соціальноекономічної моделі. У 1920-х рр. радянській владі довелося зробити відступ від своєї утопічної програми прямого товарообміну. НЕПом легалізовувалася приватна торгівля. Однак, надаючи їй певні права, держава одночасно створювала систему обмеження діяльності приватника. Цінова політика держави, яка будувалася не на економічному законі вартості, а на законах соціальної справедливості, унеможливлювала стабільне існування ринку. 3 посиленням державного та кооперативного секторів, приватна торгівля витіснялася із цієї сфери і практично припинила свою діяльність на початку 1930-х рр. Держава розгорнула боротьбу за завоювання та підпорядкування собі ринку шляхом регулювання його процесів.

Характерною рисою індустріального етапу розвитку радянської держави було становлення жорсткої командно-адміністративної системи, у рамках якої не допускалися альтернативні форми власності та господарські уклади. У цілому дієздатність цієї системи грунтувалася на праві директивного централізованого розподілу ресурсів і зовнішньоекономічного примусу.

Розвиток радянської торгівлі здійснювався у складних умовах тотального дефіциту, що обумовлювало певний час іï співіснування із системою спецрозподільників. Створені тією ж радянською системою диспропорції у співвідношенні між промисловими та сільськогосподарськими товарами, попитом і пропозиціями, «ножицями цін» на промислову та сільськогосподарську продукцію викликали необхідність розроблення економічних методів регулювання і розвитку торговельної сфери. Дії влади з ліквідації приватної торгівлі та здійснення форсованої індустріалізації спровокували у країні продовольчий дефіцит. Для стабілізації ситуації у 1928 р. було запроваджено карткову систему розподілу. Замість процедури купівлі-продажу здійснювалося отоварювання клієнтів за, так званими, «забірними книжками», через систему закритого розподілу. у товарообігу панував

\footnotetext{
${ }^{1}$ Аборвалова О.Н. Советская торговля в 30-40 гг. ХХ века // Современные исследования социальных проблем (электронный научный журнал). 2012. № 1(09). URL: https://cyberleninka.ru/article/n/sovetskaya-torgovlya-v30-40-gg-xx-veka; Дубровский А.М. Большевизм и торговля (1920-1930-е гг.) // Вестник Брянского государственного университета. 2012. № 2. С. 83-86.

${ }^{2}$ Медушевский А.Н. Сталинизм как модель социального конструирования. К завершению научноиздательского проекта // Российская история. 2010. № 6. С. 8-32; Осокина Е. Алхимия советской индустриализации. Время Торгсина. Москва: Издательство «Новое литературное обозрение», 2019. 344 с.; Осокина Е. За фасадом «сталинского изобилия»: распределение и рынок в снабжении населения в годы индустриализации (1927-1941). Москва, 1999. 271 с.; Марочко B.I. Обмін побутового золота на хліб в Україні періоду Голодомору 1932-1933 років // Український історик. 2008. № 3-4. С. 194-209.
} 
нормований розподіл, але торгівлі через відкриту мережу також надавалося великого значення.

На торгівлю державою покладалися великі надії, оскільки саме вона могла сприяти стабільному надходженню коштів до бюджету. Особливо потреба у цих надходженнях зростала у період форсованої індустріалізації. Будівництво індустріальних об'єктів у СРСР вимагало колосальних капіталовкладень. Більшість промислових підприємств епохи індустріалізації будувалися за іноземними проектами, обладнання для них потрібно було купувати за кордоном. У Кремлі розраховували, що основним джерелом фінансування об’єктів індустріалізації повинні стати експортні надходження від продажу зерна, лісу та нафти. Однак, ці плани стали програшними, оскільки світова економічна криза, яка розпочалася у жовтні 1929 р., обвалила світові ціни, особливо на зерно. Збільшення об'ємів продажу зерна не вирішувало проблему в цілому. Селянство потерпало від частих неврожаїв і голоду, а те зерно, що мало, не хотіло продавати за заниженими цінами. Ці чинники змушували державу шукати інші шляхи фінансування.

Надійними джерелами наповнення бюджету ставали грошові накопичення держави за рахунок економії ${ }^{3}$ державні позики ${ }^{4}$ та торгзінівська торгівля ${ }^{5}$ Для оплати зовнішнього боргу за кредитами країні потрібно було золото. 1 листопада 1931 р. на засіданні Політбюро ЦК ВКП(б) Й. Сталіним була озвучена доповідь «Про золото», за якою Політбюро уповноважило створену комісію у питаннях золота застосувати усі можливі заходи для збільшення золотих ресурсів країни, оскільки наявні тоді золотовалютні ресурси у розмірі 213 млн. крб. не могли покрити і третини зовнішнього боргу СРСР. Для розвитку золотодобувної промисловості бракувало імпортного устаткування, а для його закупівлі золота. Замкнуте коло не давало виходу із ситуації, що склалася ${ }^{6}$.

Порятунком могло стати вилучення цінностей у населення. Цією роботою займалося Об'єднане державне політичне управління, яке здійснювало полювання на «соціально підозрілих» (представників заможних верств дореволюційного суспільства, непманів), збирало інформацію по вкладах громадян в іноземних банках та отримання спадщини. Методи ОДПу були ефективними для вилучення великих заощаджень. Однак, населення володіло і дрібними коштовностями приватного характеру, які, помножені на багатомільйонне населення усієї країни Рад, могли сформувати величезне багатство. Потрібно було лише знайти спосіб, за якого можна було зібрати ці розрізнені цінності.

Важливим джерелом наповнення золотовалютних резервів країни стала, організована влітку 1930 р. при Наркоматі зовнішньої торгівлі СРСР, контора «Торгзін», яка займалася отоварюванням іноземних громадян і закордонних суден ${ }^{7} .3$ січня 1931 р. вона була реорганізована у Всесоюзне обєєднанн, яке в Україні мало свої філії у Києві, Харкові, Одесі. Упро-

\footnotetext{
${ }^{3}$ Директивы КПСС и советского правительства по хозяйственным вопросам: сборник документов: в 4 т. Москва: Госполитиздат, 1957. Т. 1. С. 590-596.

${ }^{4}$ Теребов В.Н. Каталог облигаций и обязательств внутренних государственных и целевых займов РСФСР и СССР, 1922-1991. Саранск: Красный Октябрь, 1996. С. 28.

${ }^{5}$ Осокина Е.А. Золото для индустриализации: «Торгсин». Москва: РОССПЭН, 2009. 592 с.

${ }^{6}$ Сельская В.А. Источники финансирования объектов индустриализации СССР в 1926-1935 гт. (на примере строительства Ярославского резино-асбестового комбината) // Вестник Ивановского государственного университета. Серия «Гуманитарные науки». 2017. Вып. 4 (17). С. 71.

${ }^{7}$ Осокина Е.А. За зеркальной дверью торгсина // Отечественная история. 1995. № 2. С. 86.
} 
довж 1931 р. в УСРР перебував постійний уповноважений московської контори, відтак сталої організаційної системи управління «Торгзіном» в УСРР тоді не існувало. Уповноважений правління Всесоюзного об'єднання «Торгзіну» в Україні одночасно керував і харківською конторою, а вся система перебувала під наглядом Наркомату зовнішньої торгівлі СРСР .

Лише у кінці червня 1932 р. Українською економічною нарадою було прийнято постанову «Про утворення Всеукраїнської контори «Торгзін», якою під протекторатом уповноваженого Наркомату зовнішньої торгівлі при Раднаркомі СРСР започатковувалася українська торгзінівська система. Всеукраїнська контора була філією Всесоюзного об’єднання «Торгзін» і створювалася для управління операціями з роздрібної торгівлі, яка здійснювалася обласними конторами на території УСРР ${ }^{9}$. Головним завданням ВУК, як і всієї системи «Торгзін» у СРСР, був пошук нових форм і методів торгівлі, які б могли принести потужне валютне поповнення державі.

3 осені 1931 р. магазини «Торгзіну», окрім обслуговування іноземців, отримали дозвіл на отоварювання і радянських громадян. Вони отримали право купувати у торгівельних точках системи «Торгзін» товари в обмін на наявні у них валюту та «домашнє» золото (ювелірні вироби, побутові предмети 3 цінних металів тощо) ${ }^{10}$. На момент появи на світ системи «Торгзін» населення СРСР уже жило на напівголодному пайку. Тому питання, в який спосіб виманити у людей побутові цінності, мало очевидну відповідь.

Торгзінівська торгівля була сповнена контрастів. Поряд з відкритими «Торгзіном» універмагами, спеціалізованими магазинами, з багатим внутрішнім інтер'єром і широким асортиментом вишуканих товарів, розрахованих на елітного покупця, існували крамниці та лабази з хамовитими та неохайними продавцями. Часто у таких торгових точках не дотримувалися санітарних норм і норм зберігання товарів, обмежувався відпуск товарів в одні руки, встановлювалися «нагрузки» і примусовий асортимент з неходових товарів. Торговельна мережа системи «Торгзін» мала й інші вади. Частими були випадки грубої поведінки продавців з покупцями, неналежного розподілу товарів між торговельними точками тощо.

Одним із головних показників торгівлі є ї̈ товарообіг. Рух товарів у радянській державній торгівлі здійснювався за законами планової економіки і під контролем влади. Виконання валютного плану в системі «Торгзін» залежало від належних умов постачання товарів, їх об’єму й асортименту, якості товарів, особливо промислової групи. Очікування директив, забюрократизованість і централізація у питаннях постачання негативно впливали на організацію торгзінівської торгівлі, спричиняли затримку у реалізації, наприклад, сезонних товарів. У період найвищого попиту на окремі групи товарів, вони із запізненням надходили до пунктів їх реалізації. При чому, ці хронічні перебої у постачанні були викликані, в основному, не їх дефіцитом, а, головним чином, неповороткістю у маневруванні товарними фондами, відсутністю вмінь і бажання швидко вирішувати питання практичного змісту на місцях. Типовим явищем ставало затоварювання магазинів одним товаром і штучне створення дефіциту інших, що також негативно впливало на товарообіг

\footnotetext{
${ }^{8}$ Марочко B.I. «Торгсин»: золота ціна життя українських селян у роки голоду (1932-1933) // Український історичний журнал. 2003. № 3. С. 90.

${ }^{9}$ Центральний державний архів вищих органів влади і управління України (далі - ЦДАВО України). Ф. 4051. Оп. 1. Спр. 39. Арк. 392.

${ }^{10}$ Семенова Ф.Ю. Деятельность Вятского отделения Всесоюзного объединения «Торгсин»... С. 25.
} 
і виконання плану. Вадами організації роботи торгівельної мережі були відсутність належної реклами товарів та інформування покупців про їх асортимент. Для цього пропонувалося посилити рекламну діяльність, організувати художнє оформлення вітрин торговельних закладів, здійснювати виставки товарів у самому магазині.

Такий стан речей у торгзінівській системі спричинив у першій половині голодного 1933 р. перебої з постачанням її торговельних точок хлібо-фуражними товарами та борошном. Найбільший попит на той час був на житнє борошно і сорти простого помелу пшеничного борошна. «Ми знаємо, що цей попит - явище тимчасове, тому його необхідно своєчасно і на повну використати», - писав у листі до Наркома зовнішньої торгівлі СРСР А. Розенгольца Уповноважений НКЗТ в Україні Й. Каттель. Керівництво «Торгзіну» підраховувало збитки з недоотримання валютної виручки по голодній Україні до 3 млн. крб. золотом ${ }^{11}$, а українські родини - втрати своїх близьких, яких можна було врятувати від голодної смерті хлібом, купленим за останні сімейні цінності.

Торгзінівській системі часто доводилося вирішувати завдання організації ефективної кадрової політики. Якість кадрів системи «Торгзін», особливо працівників торговельної мережі, була далекою від досконалості. Неналежно організовувалася робота відділів кадрів і комплектування штатів, не працювали атестаційні комісії. Однак регулярно здійснювалася робота на «злобу дня» - пошук і чистка системи від «соціально-чужих елементів», «класових ворогів», колишніх непманів, позбавленців тощо. Прикладом такої пильності щодо кадрів можуть стати матеріали доповідних записок: «Сторож магазину № 2 у Мінську С. Толкач - із колишніх священників, веде контрреволюційні розмови; касирка магазину № 3 0. Абельзон - дружина висланого валютника. У Слуцькому магазині працює А. Плавник - засуджений у 1922 р. до вищої міри соціального захисту, яка була замінена 10 роками ув'язнення. У Бегомлі завмаг І. Гулевич - темна особистість...» ${ }^{12}$. Вадами організації роботи системи ставали проблеми сімейності у забезпечення кадрами, практикувалася кругова порука, просування приватного протекціонізму.

Загалом, торгівельна мережа системи «Торгзін» була збитковою. Часто керівництво обласних контор вступало у змови, вибудовували облік і звітність так, щоб упродовж тривалого часу як у центральному апараті, так і в торгівельній мережі завуальовувати справжній стан справ, заплутувати рахунки, оприбутковувати товари на базах аж через кілька місяців після їх надходження на склад або відпускати товари універмагам ще до оприбутковування. Така організація обліку та звітності призводила до низки явно злочинних дій, бухгалтерських оформлень, як, наприклад, списання на рахунок збитків недостачі товарів в універмагах і на базах, збитки через уцінку нереалізованих вчасно товарів, у зв'язку з втратою товарами їх належного вигляду та якості, списання у збитки пені і неустойки, за несвоєчасну оплату рахунків. Також мала місце незаконна видача пайків особам, які на ї отримання не мали ніякого права, видача управлінському апарату пайків за заниженими цінами, крадіжки товарних книжок тощо. Прикладом такої збитковості та неналежної організації роботи може слугувати діяльність Білоруської контори, яка за 1933 р. принесла системі збитків на суму понад 1 млн. крб. золотом ${ }^{13}$.

\footnotetext{
${ }^{11}$ ЦДАВО України. Ф. 4051. Оп. 1. Спр. 39. Арк. 162.

${ }^{12}$ ЦДАВО України. Ф. 4951. Оп. 1. Спр. 39. Арк. 233.

${ }^{13}$ ЦДАВО України. Ф. 4951. Оп. 1. Спр. 39. Арк. 233.
} 
У січні 1934 р. на засіданні Правління Всесоюзного об’єднання «Торгзін» уповноважений Всеукраїнської контори Й. Братніков у своїй доповіді констатував факт стрімкого зростання української торговельної мережі. Цифри говорили самі за себе. Якщо станом на 1 січня 1933 р. в УСРР налічувалося 74 торговельні точки, то уже до грудня того ж року їх число зросло до 249. За бажанням виконувати завдання партії та звітуватися кількістю губилася якість. Торговельні точки (магазини, ларьки, лабази) відкривалися у населених пунктах без вивчення економічного стану окремих регіонів. Це призводило до нерентабельності роботи окремих пунктів торгівлі, тому згодом їх доводилося закривати.

Однак держава потребувала виконання плану. На 1933 р. правлінням Всесоюзного об’єднання «Торгзін» було доведено план залучення інвалютних цінностей для УСРР, який Всеукраїнською конторою було виконано на 68,5\%, план реалізації товарів - на 65,5\%, а план постачання - на 86\%. У центральному керівництві до уваги не брався справжній стан справ в Україні у голодні 1932-1933 pp. ${ }^{14}$

Основною причиною недовиконання плану Всеукраїнською конторою у Москві вважали неналежну організацію роботи. Там наполегливо рекомендували використовувати усі можливі заходи для примноження отримання валюти і золота. Зокрема, це мала бути організована виїзна торгівля, використання базарів, ярмарків і розширення мережі до 300 пунктів торгівлі. Крім того, важливим джерелом отримання валюти бачили організацію ефективної діяльності шипчандлерств - портової торгівлі. Для цього потрібно було домагатися усунення перебоїв 3 постачанням товарами іноземних суден і радянських кораблів закордонного плавання.

Окремим питанням в організації результативної діяльності усієї мережі системи «Торгзін» стояло встановлення контролю за роботою пунктів із закупівлі у населення золота, срібла та інших цінностей, належна організація отримання громадянами валютних переказів із-за кордону. Ці напрями діяльності торгзінівської системи вимагали контролю та попередження зловживань, реклами операцій з переказів. Для належної організації роботи периферійних торговельних точок при комерційних відділах обласних контор - Харківської, Одеської, Київської та Дніпропетровської - створили по два сектори: сектор міської торгівлі та сектор периферійної торгівлі з окремою інспектурою й окремими товарознавцями.

Ситуація $з$ невиконанням плану залучення валютних цінностей Всеукраїнською конторою «Торгзін» не була винятком. Така ж ситуація спостерігалася і в інших радянських республіках. Зокрема, 14 січня 1934 р. на засіданні правління Всесоюзного об’єднання «Торгзін» заслуховувалася доповідь уповноваженого по Середній Азії М. Махмудова та співдоповіді від керівників республіканських контор. За 1933 р. мережа торговельних точок там подвоїлася: 332 зросла до 68. Загалом, плани залучення валютних цінностей і реалізації товарів по республіках Середньої Азії були виконані у середньому на 89,2\% (Узбецької - 102\%; Туркменської - 56,1\%; Киргизької - 91,2\%; Таджицької - 44,6\%) ${ }^{15}$. Причини такої ситуації були уже відомі: неналежна організація розгортання мережі, особливо на периферії, слабке маневрування товарними фондами, невміння керівництва контор вчасно реагувати на зміни кон'юнктури ринку, слабка кадрова політика та відсутність належної реклами.

\footnotetext{
${ }^{14}$ ЦДАВО України. Ф. 4951. Оп. 1. Спр. 154. Арк. 19.

${ }^{15}$ ЦДАВО України. Ф. 4051. Оп. 1. Спр. 39. Арк. 239.
} 
У Москві з таким станом речей миритися не збиралися. У республіках мали використати усі можливості для безумовного виконання планів. Мета - максимальне вилучення у населення валюти, золота й інших цінностей - виправдовувала засоби, серед яких: маневрування товарними фондами, максимальне розширення торгівельної діяльності, забезпечення торгових точок дефіцитними товарами, автотранспортом, пошук шляхів підвищення рентабельності закладів торгівлі, залучення до роботи кваліфікованих кадрів, особливо на посади приймальників цінностей тощо.

Заклади системи «Торгзін» намагалися розширювали сервіс. У грудні 1934 р. головою правління Всесоюзного об'єднання «Торгзін» М. Левенсоном було видано розпорядження, в якому, з огляду на негативні явища, що були притаманними закладам торгзінівської торгівлі та з метою максимального залучення клієнтів, при універмагах організовувалися спеціальні столи індивідуальних замовлень. На них покладалося завдання здійснення прийому від населення замовлень на усі види товарів і предметів номенклатури «Торгзіну». У магазинах організовувалися Бюро попередніх замовлень. Заготовлені на визначений час товари могли бути видані покупцеві самим магазином або за окрему плату доставлятися додому на домовлений час. У разі здійснення попередньої оплати, замовлення товарів та їх доставку можна було здійснювати і по телефону ${ }^{16}$.

Отже, здійснення «революції зверху» у другій половині 1920-х - першій половині 1930-х рр. серйозно вплинуло на усі сфери життя радянського суспільства та визначило основні напрямки його розвитку на тривалу історичну перспективу. Для цього історичного періоду був характерним мобілізаційний тип економіки. Будівництво соціалізму в окремо взятій країні суттєво обмежило господарські ресурси радянської влади, змушуючи до максимальної концентрації наявних в її розпорядженні засобів і пошуку нових ресурсів. Радянська державна система управління торгівлею у 1920-х - 1930-х рр. еволюціонувала від повного заперечення торгівлі як явища, що не могло бути властивим новому радянському суспільству, до перетворення ï у важливу складову радянської соціальноекономічної моделі.

Державне регулювання торгівлі цього періоду не було соціально-орієнтованим. У питаннях постачання радянська влада притримувалася індустріальних пріоритетів. Рішення влади не завжди були обумовлені економічними, а швидше політичними причинами і створення та поширення системи «Торгзін» яскравий тому приклад. Торгзінівська торгівля виконала своє головне завдання: вона допомогла радянській владі отримати засоби для потреб індустріалізації. Практично усі валютні цінності, що зберігалися у державі після лихоліття 1917-1920 рр., накопичені за періоду НЕПу, у цинічний по відношенню до власного народу спосіб були вилучені державою для здійснення планів індустріалізації.

\footnotetext{
${ }^{16}$ ЦДАВО України. Ф. 4051. Оп. 1. Спр. 39. Арк. 341.
} 


\section{Features of Soviet Domestic Trade During the Late 1920s - the Early 1930s}

Abstract: The article studies the features of Soviet domestic trade under the conditions of a centralized economy, as well as its search for financial resources to implement the industrialization programme in the country. The article finds that the Soviet system of trade management shifted from a complete denial of trade as it is to its becoming an important factor in the Soviet socio-economic model. The country's price policy followed the principles of social justice rather than the law of value, thus making it impossible for the market to exist stably.

The then state regulation of trade cannot be called socially oriented. In matters of supply, the Soviet government adhered to industrial priorities. The effectiveness of this system relied on the right of directive centralized distribution of resources and foreign economic coercion.

Soviet trade developed under difficult conditions of the total deficit, which led to its coexistence with the system of special distributors for a certain time. A reliable source of budget replenishment was the state's savings due to economy cuts, government loans and Torgsin, the state corporation for trade with foreigners.

The implementation of the Torgsin currency plan depended on proper conditions of supply of goods and their volume, range and quality, especially those of the industrial group. The mission of the Torgsin system was to find new forms and methods of the trade that could bring a powerful currency effect to the state.

The article proves that the Torgsin system accomplished its mission. Indeed, it had helped the Soviet government to obtain funds for the needs of industrialization.

Keywords: USSR, UkrSSR, Soviet trade, state regulation, industrialization, currency, Torgsin 